Wojciech Goleński

ORCID: 0000-0001-8936-4510

Uniwersytet Opolski

Andrzej Rączaszek

ORCID: 0000-0003-1178-0789

Uniwersytet Ekonomiczny w Katowicach

\title{
Diagnoza i analiza funkcjonowania organizacji pozarządowych w obszarze opieki w Polsce. Wnioski z badań empirycznych*
}

DOI: 10.19195/1643-0328.25.4

Słowa kluczowe: opieka, organizacje pozarządowe, trzeci sektor

\section{Wprowadzenie}

Organizacje obywatelskie (NGO) jako instytucje opiekuńcze bądź szerzej rozumiane podmioty polityki społecznej (działające w obszarze pomocy społecznej, edukacji, ochrony zdrowia) są uznawane za niezbędne ogniwo lokalnych systemów opieki. Ten tzw. trzeci sektor ma w założeniu kompensować niedostatki instytucji publicznych i podmiotów rynkowych w dostarczaniu dóbr i usług lokalnym społecznościom. Miniony kryzys finansowy datowany od 2007 r. raz jeszcze uświadomił politykom społecznym potrzebę zredefiniowania wizji tego, jaką rolę powinni ogrywać poszczególni aktorzy (państwo, rynek, społeczeństwo) w kształtowaniu ogólnospołecznego dobrobytu. Ściśle państwowa (publiczna), w znacznej mierze scentralizowana polityka publiczna, choć teoretycznie zastąpiona działaniami samorządów, w wielu swoich założeniach nie należy w Polsce bynajmniej do przeszłości ${ }^{1}$. Na skutek niekorzystnych tendencji demograficznych, procesu starzenia się ludności, chorób cywilizacyjnych bądź po prostu braków

* Badanie „Diagnoza i analiza funkcjonowania formalnych i nieformalnych instytucji opieki w Polsce” zostało zrealizowane przez PBS sp. z o.o. na potrzeby Centrum Rozwoju Zasobów Ludzkich — jednostki budżetowej podległej Ministrowi Pracy i Polityki Społecznej. Artykuł wykorzystuje dane i wnioski zawarte w raporcie cząstkowym dotyczącym działalności organizacji pozarządowych w sześciu celowo dobranych powiatach (próba NGO1) z września $2015 \mathrm{r}$. 
instytucjonalnych, widocznych szczególnie na prowincji, w procesie dostarczania usług opiekuńczych działalność instytucji publicznych jest, i prawdopodobnie będzie, niewystarczająca. Z kolei instytucje rynkowe (komercyjne) nie zawsze są zainteresowane ich dostarczaniem (niewielka stopa zwrotu). Zgodnie z prawem popytu i podaży rola sektora obywatelskiego w tej sferze będzie bez wątpienia wzrastać (co jest zgodne z opiniami respondentów biorących udział w badaniu). Niemniej w chwili obecnej znaczenie NGO jako dostarczyciela usług opiekuńczych jest oceniane w znacznym stopniu ambiwalentnie. Dodatkowo za Kramerem należy wskazać, że dominującą w ostatnich latach tendencją jest konwergencja i zacieranie granic między sektorami, co sprawia, że w analizie trzeciego sektora zderzają się przeciwstawne punkty widzenia. Dominujące stanowisko akcentuje szybką instytucjonalizację organizacji pozarządowych jako podstawowego partnera dla państwa (samorządów) w świadczeniu usług oraz orzecznictwa. Inne stanowisko uwypukla znaczenie przełamywania granic międzysektorowych i rosnącego znaczenia współzależności różnych aktorów ${ }^{2}$. Analiza funkcjonowania sektora obywatelskiego w obszarze opieki ma także inną podstawę. Lokalna polityka społeczna formalnie oparta jest na zasadzie subsydiarności (pomocniczości). Zasada ta może być stosowana w obrębie podmiotów publicznych (delegacja zadań do niższych szczebli władz samorządowych), ale w przypadku tzw. pomocniczości horyzontalnej dotyczy powierzania zadań podmiotom obywatelskim. Oznacza to nie tylko konieczność partycypacji społecznej, ale także szczególną formę deregulacji. Zasada subsydiarności jest zatem ściśle związana z zasadą decentralizacji ${ }^{3}$, która ma dwie podstawy — socjopolityczną, związaną z upodmiotowieniem środowisk lokalnych, oraz ekonomiczną, która odnosi się do większej efektywności usług społecznych poprzez lepsze dostosowanie ich specyfiki do potrzeb odbiorców ${ }^{4}$. Z uwagi na oddolny charakter NGO stanowią element subsydiarnej i zdecentralizowanej lokalnej polityki społecznej.

Artykuł prezentuje wybrane wyniki i wnioski z badań, dotyczących diagnozy i analizy funkcjonowania organizacji pozarządowych jako elementów systemu opieki w Polsce. Materiał empiryczny uzyskano w trakcie indywidualnych wywiadów pogłębionych (IDI) przeprowadzonych z przedstawicielami NGO z wybranych i mocno zróżnicowanych pod wieloma względami powiatów: m. Skierniewice, m. Olsztyn, nyskiego, bieruńsko-lędzińskiego, kazimierskiego, wejherowskiego. W próbie badawczej znalazły się organizacje społeczne przyjmujące następujące formy organizacyjne: stowarzyszenia, fundacje, kościelne osoby prawne, towarzystwa i koła (będące de facto stowarzyszeniami),

${ }^{1}$ W. Goleński, Rola odpowiedzialności obywatelskiej w modelu aktywnej polityki społecznej, [w:] Odpowiedzialność - przestrzeń lokalnego społeczeństwa obywatelskiego, biznesu i polityki, red. R. Geisler, Opole 2013, s. 30.

2 R.M. Kramer, Trzeci sektor w trzecim tysiącleciu, [w:] Trzeci sektor dla zaawansowanych. Współczesne teorie trzeciego sektora - wybór tekstów, Warszawa 2006, s. 228.

3 W. Koczur, Decentralizacja jako podstawa skutecznego rozwiązywania lokalnych problemów społecznych, [w:] Partnerstwo lokalne jako strategia rozwiązywania problemów społecznych, red. A. Frączkiewicz-Wronka, Katowice 2010, s. 86-87.

4 R. Wasylewski, Lokalna polityka społeczna, [w:] Polityka społeczna, red. G. Firlit-Fesnak, M. Szylko-Skoczny, Warszawa 2007, s. 352-353. 
podmioty gospodarki społecznej (spółdzielnie socjalne). Badanie obejmowało łącznie 60 IDI. W poszczególnych powiatach liczba przeprowadzonych wywiadów wahała się od 5 do 15 , co było podyktowane faktyczną dostępnością respondentów oraz lokalnym nasyceniem NGO. Znaczenie i rola organizacji pozarządowych w poszczególnych powiatach są więc bardzo zróżnicowane zarówno w sensie jakościowym (zakres i typ prowadzonej działalności), jak i ilościowym (liczba organizacji działających w obszarze opieki). Wnioski zawarte $\mathrm{w}$ artykule są próbą syntezy aktywności sektora społecznego, która z przytoczonych powyżej powodów musi być niedoskonała. Można jednak przyjąć, że pewne elementy determinujące potencjał opiekuńczy NGO są wspólne dla badanych podmiotów niezależnie od innych czynników składających się na charakterystykę poszczególnych powiatów.

\section{Opieka jako forma działań organizacji pozarządowych}

Specyfika funkcjonowania organizacji pozarządowych, ich faktyczna i potencjalna niezależność od sektora publicznego oraz często podkreślana innowacyjność, nieszablonowość, solidaryzm $^{5}$ sprawiają, że niezwykle trudne jest ujednolicenie definicyjne opieki realizowanej przez te podmioty. Uzyskany materiał empiryczny nie pozostawia w tej kwestii wątpliwości. Definicje opieki artykułowane przez respondentów są w znacznym stopniu zindywidualizowane. Często odbiegają od formalnego jej zdefiniowania, obowiązującego przedstawicieli instytucji publicznych (jak ma to miejsce np. w przypadku służb społecznych — art. 68 ustawy o pomocy społecznej). Kolejną komplikacją jest fakt zróżnicowania typu organizacji oraz obszarów ich działalności. Niemniej na podstawie wypowiedzi respondentów ustalono, że opieka to wielostronne i kompleksowe działania mające na celu udzielanie osobom potrzebującym pomocy $\mathrm{i}$ wsparcia w samodzielnym funkcjonowaniu, z uwzględnieniem ich potrzeb zdrowotnych, materialnych, społecznych i emocjonalnych.

Organizacje pozarządowe w Polsce zajmują się różnorodną działalnością publiczną, ale niekoniecznie wszystkie obszary ich aktywności można zakwalifikować do szeroko rozumianej polityki społecznej ${ }^{6}$. W prezentowanej analizie kryterium wyodrębnienia konkretnych podmiotów do badania było pochodną ich umiejscowienia $\mathrm{w}$ jednym ze wskazanych powyżej powiatów. $Z$ powodu bardzo zróżnicowanej aktywności sektora $\mathrm{w}$ układzie powiatowym $\mathrm{w}$ analizie uwzględniono także podmioty, które potencjalnie nie mają wiele wspólnego $\mathrm{z}$ realizacją funkcji opiekuńczych na rzecz dzieci do lat 5-6, osób starszych, niepełnosprawnych i długotrwale chorych (np. małe stowarzyszenia prorozwojowe, koła gospodyń wiejskich). Jednakże podmioty te, jako nieliczne, a czasami jedyne NGO na danym obszarze (wieś, gmina), w szerszym zakresie realizują zadania, które zgodnie z przyjętą definicją należy uznać za świadczenie opieki. Działalność opie-

${ }^{5}$ Zob. J. Boschee, Migracja od innowacyjności do przedsiębiorczości, [w:] Przedsiębiorstwo społeczne. Antologia kluczowych tekstów, red. J.J. Wygnański, Warszawa 2008.

${ }^{6}$ M. Grewiński, Wielosektorowa polityka społeczna. O przeobrażeniach państwa opiekuńczego, Warszawa 2009, s. 224-225. 
kuńcza, w świetle powyższej definicji, obejmuje bardzo szeroki katalog aktywności. Są to zarówno działania związane z aktywizacją i rehabilitacją społeczną, jak i działania w sferze rehabilitacji fizycznej oraz leczenia. W pierwszym przypadku podejmowane są inicjatywy związane m.in. z aktywnym spędzaniem wolnego czasu, nauką, nabywaniem kompetencji „miękkich”, integracją społeczną. Rzadko natomiast realizowane są zadania związane $\mathrm{z}$ aktywizacją zawodową (ma to miejsce w spółdzielniach socjalnych). W przypadku rehabilitacji sensu stricto i lecznictwa katalog podejmowanych działań jest także bardzo szeroki. Efekty działalności opiekuńczej są często niewymierne, trudno je jednoznacznie wskazać. W przypadku osób niepełnosprawnych i długotrwale chorych rehabilitacja, terapia zajęciowa, wsparcie psychologiczne i inne działania nie przynoszą spektakularnych efektów w krótkiej perspektywie czasowej. Podobnie jest w przypadku dzieci zagrożonych marginalizacją. Efektem prowadzonych działań opiekuńczych jest często tzw. wyjście na prostą, co jest dostrzegane przez opiekunów, rodziny, osoby, które miały kontakt z podopiecznymi przez dłuższy czas, jako kluczowe dla zmiany statusu społecznego. Nie jest to natomiast wymierne i łatwe do wskazania przez środowisko zewnętrzne.

W niektórych zrzeszeniach/organizacjach opieka świadczona jest na zasadzie samopomocy - grupa osób wymagająca opieki na skutek np. choroby lub niepełnosprawności podejmuje oddolne działania na swoją rzecz. $\mathrm{W}$ innych podmiotach opieka polega na prowadzeniu przez organizację formalnej instytucji opieki (np. warsztatów terapii zajęciowej, agencji usług opiekuńczych) lub działalność danego zrzeszenia jest zainicjowana odgórnie (przez samorząd lub podmiot komercyjny — np. korporacja, duży zakład produkcyjny, kopalnia). Formy świadczenia opieki obejmują zarówno formy instytucjonalne (placówki opiekuńcze), jak i środowiskowe (opieka realizowana w najbliższym środowisku podopiecznego). Generalnie respondenci uznawali konieczność funkcjonowania obu form, zależnie od sytuacji konkretnej osoby wymagającej opieki oraz możliwości zapewnienia wsparcia. Zasadny wydaje się więc wniosek, że formy i zakres świadczonej opieki przez NGO są bardzo zróżnicowane i zależne od istniejących możliwości oraz otoczenia społecznego, a sama opieka rozumiana jest z uwzględnieniem szerszego kontekstu jej świadczenia.

\section{Motywy podejmowania działalności przez organizacje pozarządowe}

Motywy powstawania analizowanych organizacji związane są przede wszystkim z występowaniem określonych potrzeb w poszczególnych powiatach. Często jest nią brak publicznych instytucji zajmujących się opieką. W wypowiedziach powtarzały się motywy związane z chęcią niesienia pomocy/świadczenia opieki przez osoby o znacznym poziomie wrażliwości i empatii oraz takie, których bliscy wymagali bezpośredniej opieki (najczęściej osoby chore i niepełnosprawne). W niektórych przypadkach działania związane z opieką są jedynie elementem inicjatyw związanych $z$ szerzej rozumianym lokalnym rozwojem społecznym. Jest to znamienne, ponieważ z jednej strony ukazuje niebagatelne znaczenie organizacji pozarządowych, które kompensują niedostatki w wielu sferach działalności publicznej, w tym samorządowej, z drugiej strony wskazuje, że sferę opieki często trudno 
oddzielić od kwestii związanych z szerzej rozumianym rozwojem ${ }^{7}$. Również beneficjenci opieki nie stanowią jednorodnej grupy. Badanie dotyczyło opieki nad czterema kategoriami odbiorców (dzieci do 5-6 lat, osoby starsze, niepełnosprawne i długotrwale chore). Opieka świadczona jest w przeważającej większości na rzecz konkretnych osób, a nie instytucji opiekuńczych (wyjątek stanowi np. stowarzyszenie zbierające środki na rzecz jednego z oddziałów lokalnego szpitala czy stowarzyszenie związane z prowadzeniem placówek edukacyjnych).

My nie współfinansujemy żadnej organizacji innej, czy opieki społecznej, czy czegokolwiek. My się zajmujemy przede wszystkim, może tak zróbmy, że pojedynczymi osobami. Kto się do nas zgłosi, organizujemy turnusy rehabilitacyjne. Czyli pośredniczymy, wysyłamy ludzi, czy robimy wczasy dla seniorów. NGO1_N_S_1_11082015

Z całą stanowczością trzeba wskazać, że kategoria osób niepełnosprawnych najczęściej znajdowała się w orbicie zainteresowań podmiotów obywatelskich. Zdaniem respondentów ta kategoria znajduje się w najtrudniejszej sytuacji na skutek drastycznych braków w infrastrukturze opiekuńczej (szeroko rozumianej) i barier utrudniających dostęp do przestrzeni publicznej, szczególnie na prowincji. Znaczna część podmiotów świadczy opiekę dla więcej niż jednej grupy odbiorców. Często trudno wskazać dominującą kategorię beneficjentów, gdyż głównym kryterium objęcia opieką jest np. choroba/niepełnosprawność albo wiek. Obrazuje to przytoczony poniżej cytat:

[...] Po prostu była potrzeba do reprezentowania naszych interesów z racji braku stosownych standardów leczenia w Polsce, więc w około 40 paru pacjentów spotkaliśmy się i powołaliśmy stowarzyszenie, żeby jako organizacja pozarzadowa o te swoje prawa trochę powalczyć, ale jednocześnie zaplanować wspólna informację, edukację, wsparcie. Wieloletnie działanie w kierunku reprezentowania interesów naszych, naszych, czyli pacjentów ze szpiczakiem. Zwłaszcza, że sq oni bardzo skutecznie ignorowani przez wszelkie instytucje $z$ reguly przede wszystkim dlatego, $\dot{z}$ e jest to choroba niemedialna, bo jest to choroba ludzi starszych, dobrze po sześćdziesiątce. NGO1_O_CH_2_17082015

Problemy społeczne i demograficzne, warunkujące zwiększenie zapotrzebowania na opiekę świadczoną wobec osób starszych, nie znajdują bezpośredniego odzwierciedlenia w liczbie NGO działających na ich rzecz. Bez wątpienia można podkreślić znaczące braki instytucji, takich jak: żłobki i przedszkola, domy dziennego pobytu czy uniwersytety trzeciego wieku w niewielkich miejscowościach, pomimo znacznych potrzeb w tym zakresie.

\section{Zasoby i nakłady organizacji pozarządowych}

Trzeci sektor bez wątpienia cierpi na deficyty w obszarze zasobów materialnych i finansowych. NGO zazwyczaj wykorzystują infrastrukturę (budynki, wyposażenie) użyczone przez jednostki samorządu terytorialnego lub inne podmioty (zwykle nieodpłatnie).

My nie mamy własnych żadnych praktycznie pomieszczeń, lokum. Korzystamy z pomieszczeń parafii naszej. [...] Przed kilkunastu laty żeśmy to adaptowali. Odnowiliśmy to, tam jest stołówka. [...] My własnych lokali, własnych zasobów jakichś tam nie posiadamy. NGO1_N_N_2_12082015

7 Por. W. Goleński, Spółdzielczość socjalna jako element zrównoważonego rozwoju, „Przegląd Nauk Stosowanych" 2014, nr 4 (4). 
Środki finansowe w dyspozycji sektora społecznego są bardzo skromne. Podmioty obywatelskie nie są również niezależne finansowo. Wskazuje się, że poprzez przepływy finansowe od samorządów i państwa organizacje pozarządowe wyręczają sektor publiczny w obowiązku świadczenia opieki (co zostanie szerzej nakreślone przy okazji opisu współpracy międzyinstytucjonalnej). Większość respondentów narzeka na zasoby finansowe swoich organizacji. Zasoby te uznaje za niewystarczające w stosunku do potrzeb. Źródła finansowania, oprócz grantów, kontraktów czy dotacji, obejmują: składki członkowskie, darowizny (głównie w przypadku fundacji), odpisy 1\% podatku dochodowego od osób fizycznych (w przypadku podmiotów posiadających status organizacji pożytku publicznego) oraz dochody z prowadzonej działalności (spółdzielnie socjalne). Niemniej ważne są także darowizny od sponsorów.

Darowizny różne na stowarzyszenie od miejscowych przedsiębiorców. Jak realizujemy jakiś turniej, czy jakąś imprezę, że tak powiem, no to się ubiegamy o wsparcie. Téz nie możemy narzekać, bo z reguly to nawet cośtam dają. NGO1_K_(4)

Jednakowoż w IDI pojawiają się wątki zmniejszającego się zaangażowania sponsorów w działania opiekuńcze, co w przypadku realnych możliwości prowadzenia działań przez organizacje funkcjonujące na zasadach non profit ma ogromne znaczenie. Wydawać by się mogło, że możliwość finansowania działalności stanowią liczne projekty ze środków Unii Europejskiej. Nie wszystkie organizacje korzystają z projektów (większość nie korzysta). Powodem jest biurokracja oraz problemy z rozliczaniem poszczególnych działań. Niesprzyjającym czynnikiem jest $\mathrm{w}$ tym przypadku także postawa przedstawicieli administracji publicznej zajmujących się przyznawaniem i rozliczaniem projektów, np. POKL.

[POKL - przyp.] Urzędnicy traktuja to znowu [zastanowienie] jak naciagaczy, że my ich wszystkich chcemy naciagnąć, bo oni dają parę groszy. [...] Niemiłe wspomnienie, kontrole, bo o 2 grosiki było źle wydane. Tak to wyglada. NGO1_B_N_3_25082015

Zasoby kadrowe sektora oparte są w przeważającej części na aktywności wolontariuszy. Małe organizacje realizujące głównie działania wspierające, a także prowadzące aktywizację społeczną mogą z powodzeniem wykorzystywać chęci i zaangażowanie wolontariuszy. W przypadku prowadzenia opieki medycznej czy rehabilitacji konieczne jest zatrudnienie płatnego personelu, gdyż wymagają one specjalistycznej wiedzy i kompetencji. Generalnie zasoby kadrowe NGO zajmujących się opieką są oceniane jako wystarczające. Ale respondenci wskazują jednocześnie na kryzys postaw altruistycznych i zmniejszające się zaangażowanie obywatelskie (brak kapitału społecznego). Wskazują ponadto na coraz powszechniej występujące postawy roszczeniowe zarówno wśród samych podopiecznych, jak i ich rodzin. Jest to tym bardziej niepokojące, że w wielu przypadkach to zaangażowanie najbliższego otoczenia stanowi podstawę wypracowania odpowiednich efektów. Organizacja pozarządowa niejednokrotnie zakłada jedynie większe lub mniejsze wsparcie w opiece.

Czasami, proszę mi wierzyć, sa rodziny tak roszczeniowe, że by chcialy wszystko łącznie $z$ tym, żeby pielegniarka myła, kąpała chora osobę i wszystko robiła. Wszystko, tak naprawdę wyręczała rodzinę. NGO1_S_09092105 


\section{Współpraca międzyinstytucjonalna}

Sektor obywatelski, jako istotny element systemowo pojmowanej lokalnej polityki społecznej, powinien funkcjonować w oparciu o wypracowane partnerstwa. Podstawą jest współpraca pomiędzy partnerami reprezentującymi różne obszary życia społeczno-gospodarczego. Partnerzy w sposób trwały i systematyczny projektują i realizują działania mające na celu budowanie tożsamości lokalnych społeczności oraz spójnego środowiska lokalnego, w którym każdy obywatel ma odpowiednie warunki osobistego rozwoju ${ }^{8}$. Współpraca stanowi warunek tworzenia kapitału społecznego w lokalnych wspólnotach, będąc jednocześnie skutkiem jego występowania. Ma to niebagatelne znaczenie w procesie zapewniania opieki tym, którzy jej wymagają, angażując przedstawicieli różnych środowisk oraz instytucji. Są to najczęściej wójtowie, burmistrzowie, przedstawiciele ośrodków pomocy społecznej, organizacji pozarządowych, podmiotów ekonomii społecznej, kościołów oraz biznesu. Włączenie sektora społecznego w ramy lokalnego partnerstwa jest szczególnie istotne z punktu widzenia budowy zaufania do trzeciego sektora. Zaufanie jest, jak wiadomo, jedną z podstaw kapitału społecznego 9 . Pozwala zaistnieć organizacjom społecznym w świadomości lokalnej zbiorowości - zakorzenić się społecznie ${ }^{10}$. $\mathrm{W}$ aspekcie gospodarczym wypracowanie partnerskiego zaufania ułatwia natomiast znalezienie niszy rynkowej, międzyinstytucjonalną kooperację, co pozwala na redukcję kosztów transakcyjnych, a tym samym większą efektywność prowadzonej działalności. Jak wskazują przedstawiciele Fundacji Barka, najistotniejszym warunkiem partnerstwa jest nieustanna edukacja jego członków oraz środowiska lokalnego. Powinna ona oprócz aspektów czysto merytorycznych obejmować także działania kształtujące odpowiednie postawy, m.in. poprzez aktywne współuczestniczenie podmiotów w życiu społeczności lokalnej ${ }^{11}$.Trzeci sektor powinien kompensować niedostatki państwa i rynku, a międzysektorowa współpraca musi cechować się komplementarnością. Usługi opiekuńcze, generowane przez podmioty reprezentujące rożne sektory, mają być z założenia zbiorem działań opartych na sprawności i efektywności ${ }^{12}$. W istocie nie zawsze ma to miejsce. Znaczna część organizacji nie uczestniczy np. w konsultacjach społecznych organizowanych przez samorząd. Utrudnia to przepływ informacji między sektorami i de facto uniemożliwia właściwe rozpoznanie sytuacji w sferze opieki. Nie jest to jednak regułą.

${ }^{8}$ L. Węsierska, Partnerstwa lokalne - droga do budowania spójności społecznej, [w:] Rozwój. O tym jak integracja środowisk lokalnych i uspołecznienie gospodarki budują nowa jakość, red. T. Sadowski, Poznań 2012, s. 9.

9 P. Sztompka, Zaufanie. Fundament społeczeństwa, Kraków 2007, s. 244; R.D. Putnam, Demokracja w działaniu. Tradycje obywatelskie we współczesnych Włoszech, tłum. J. Szacki, Kraków-Warszawa 1995, s. 258 .

${ }^{10}$ M. Granovetter, Economic action and social structure: The problem of embeddedness, „American Journal of Sociology" 91, 1985.

${ }^{11}$ L. Węsierska, op. cit., s. 11.

12 M. Grewiński, A. Karwacki, Pluralizm i międzysektorowa współpraca w realizacji usług społecznych, Warszawa 2009, s. 33. 
Naszego stowarzyszenia nikt [...] nie bierze pod uwagę. Bardziej licza się DPS-y, siostry jakieś, które pomagaja. [...] My nieformalnie dużo rzeczy robimy, to nas nie biora pod uwagę. Nie zaistnieliśmy jeszcze wświadomości tej władzy. Ta pani, u której składam projekty, mnie kojarzy. Ale nie trafitam do listy mailingowej jeszcze. Powinnam tam częściej chodzić. [...] Ja nie śledzę pod tym kątem stron internetowych, takich konsultacji. Nie trafia to do mnie i nie szukam sama. NGO1_W_CH_2_19082015

Organizacje społeczne współpracują z innymi instytucjami obywatelskimi, publicznymi oraz rynkowymi. W ostatnim przypadku współpraca dotyczy głównie pozyskiwania środków na działalność i ma miejsce najrzadziej. W przypadku najczęstszej współpracy z NGO analizowane podmioty przeważnie opierają się na nieformalnych i nieobligatoryjnych porozumieniach, a ze współpracą nie wiązały się przepływy finansowe. Jest ona oparta o regułę wzajemności. Niemal równie często organizacje współpracują z sektorem publicznym. Oparta o formalne porozumienia (częsty wyjątek stanowi nieformalna współpraca z ośrodkami pomocy społecznej) współpraca jest regularna i zazwyczaj wynika z dotowania organizacji pozarządowych przez sektor publiczny. Współpraca ta nie ma charakteru partnerstwa, ale jest wysoko oceniana. Władza lokalna coraz częściej zdaje sobie sprawę ze znaczenia NGO jako ważnych ogniw lokalnego systemu opieki. Daje temu wyraz poniższa wypowiedź:

Ja jestem bardzo szczęśliwa, bo z jej strony jest duże wsparcie i ja się cieszę, że moge pomóc. Ta osoba jest bardzo serdeczna, tak samo jak inni pracownicy pomocy społecznej, z którymi współpracuję. [...] Jeżeli oni chca im pomóc, a widzą, że gmina ma ograniczone środki, to wiedza, że mogq do mnie napisać. NGO1_W_CH_1_17082015

Ścisła współpraca z sektorem publicznym jest jednakże pewnym zagrożeniem dla tożsamości organizacji i ich faktycznej niezależności. Przeprowadzona analiza wykazała, że w znaczącej liczbie przypadków podmioty obywatelskie są uzależnione od zewnętrznych źródeł finansowania w postaci dotacji i zleceń od instytucji publicznych. Wprawdzie niejako naturalną sytuacją jest fakt czerpania środków przez organizacje obywatelskie od samorządów i władz centralnych (np. NFZ, PFRON), jednakże problemem jest tu brak dywersyfikacji źródeł finansowania. Powoduje to całkowite uzależnienie prowadzonych działań od kontraktów, wytycznych i sugestii przedstawicieli sektora publicznego. NGO nie mogą sobie pozwolić na innowacyjność z uwagi na zarzuty niezasadności wydatkowania uzyskanych środków i groźby wstrzymania ich finansowania. Z jednej strony stanowi to barierę dla wszelkiego rodzaju nadużyć, ale z drugiej strony powoduje brak niezależności, wspomnianej innowacyjności i stopniowe przejmowanie przez takie podmioty elementów kultury organizacyjnej typowych dla instytucji publicznych. Jest to wskazywany w literaturze jeden z symptomów utraty niezależności organizacji $^{13}$. Być może rozwiązaniem tego problemu mogłaby być ekonomizacja organizacji pozarządowych ${ }^{14}$, stopniowe przyjmowanie przez nie form gospodarki społecznej. Jak twierdzi J.J. Wygnański, proces ekonomizacji nie musi mieć charakteru komercyjnego.

13 J.M. Brinkerhoff, Ramy definicyjne partnerstwa pomiędzy sektorem rządowym a organizacjami non-profit, [w:] Trzeci sektor dla zaawansowanych. Współczesne teorie trzeciego sektora - wybór tekstów, Warszawa 2006.

14 Zob. J.J. Wygnański, Ekonomizacja organizacji pozarządowych. Możliwość czy konieczność?, Warszawa 2008. 
Nie chodzi tu bowiem o wypracowanie środków własnych pozwalających na uzyskanie właśnie większej niezależności. Ekonomizację można uznać za próbę „wymknięcia się” ze swoistej pułapki zależności od administracji publicznej i filantropii. Jest to szansa na zdobywanie środków na działania własne organizacji, odzyskanie „wewnątrzsterowności” i odchodzenie od postawy „wyciągniętej ręki”, od całkowitego uzależnienia od publicznych i prywatnych donatorów. Proces ten pozwala uniknąć sytuacji, w której organizacje stają się „przedłużeniem” instytucji publicznych albo zakładnikiem filantropijnej przychylności ${ }^{15}$. Badanie jednakże wykazało słabość podmiotów ekonomii społecznej w obszarze opieki. Jedynie niewielka część podmiotów non profit podejmuje inicjatywy mogące zostać uznane za przejaw ekonomizacji.

\section{NGO w lokalnych systemach opieki}

Rola i znaczenie organizacji obywatelskich jako podmiotów świadczących opiekę w lokalnych zbiorowościach nie może być jednoznacznie oceniona. Sektor obywatelski w analizowanych powiatach jest bardzo niejednorodny. W jego ramach funkcjonują zarówno podmioty świadczące opiekę dla kilku tysięcy beneficjentów (jedno ze stowarzyszeń działających na rzecz byłych i obecnych pracowników zakładu przemysłowego czy organizacja kościelna prowadząca stacje opieki w większości gmin jednego z powiatów), które mają ogromne znaczenie dla lokalnego środowiska, jak i małe podmioty (takie jak koła gospodyń wiejskich), których znaczenie jest również trudne do przecenienia na poziomie mikro. Poszczególne formy świadczenia opieki także mogą podlegać odmiennemu wartościowaniu. W przypadku istnienia znaczących braków instytucjonalnych w obszarze opieki zdrowotnej i rehabilitacji fizycznej na dalszy plan schodzą inicjatywy związane z aktywizacją i rehabilitacją społeczną. Nie można wszakże zapominać, że edukacja społeczna oraz partycypacja pozwalają ograniczać negatywne stereotypy, które stanowią jedną z przeszkód tworzenia kapitału społecznego, ograniczając potencjał rozwojowy NGO oraz środowiska lokalnego. Z tego względu lepiej uznawać opiekę medyczną, rehabilitację fizyczną oraz społeczną za sfery komplementarne, bez wskazywania, która $\mathrm{z}$ tych sfer jest najważniejsza. Tym bardziej, że w odniesieniu do niektórych kategorii beneficjentów (osoby niepełnosprawne intelektualnie czy osoby chore psychicznie) trudno jest wyznaczyć granicę między tymi sferami. Niemniej respondenci często dokonują oceny opieki w obszarze ochrony zdrowia. Są to oceny wskazujące na ogromne braki w tym zakresie zarówno pod względem ilościowym, jaki jakościowym. Dotyczy to całej próby badawczej, ale jest zróżnicowane, jeżeli chodzi o skalę w poszczególnych powiatach.

W tym miejscu warto zaprezentować, z konieczności wyrywkowe, charakterystyki poszczególnych powiatów. W przypadku Olsztyna trzeci sektor jest bardzo aktywny w obszarze opieki. Organizacje podejmują szereg działań na rzecz wszystkich kategorii beneficjentów. Opieka świadczona w mieście może być oceniona pozytywnie z uwagi na fakt, że ośrodek ma status miasta wojewódzkiego, co bez wątpienia sprzyja działalności

15 Ibidem, s. 9. 
obywatelskiej. Podobna ocena może dotyczyć obszaru Skierniewic. Organizacje społeczne są tu aktywne i rozszerzają swoją działalność. W przyszłości prawdopodobnie będą odgrywać coraz donioślejszą rolę. Wszystkie kategorie odbiorców opieki mogą liczyć na pomoc skierniewickich NGO. Zarówno Olsztyn, jak i Skierniewice mają status miast na prawach powiatu, co bez wątpienia sprzyja konsolidacji działań opiekuńczych. W przypadku pozostałych powiatów organizacje społeczne najprężniej działają w powiecie nyskim. Jednakże na ogólną ocenę wpływa tu aktywność dużej organizacji prowadzącej usługi opiekuńcze głównie w obszarze ochrony zdrowia (kościelna osoba prawna), co przekłada się na znaczne zaplecze instytucjonalne (np. w 6 na 9 gmin powiatu funkcjonują stacje opieki medycznej). Niemniej ważne jest znaczenie stolicy powiatu - Nysa jest stosunkowo dużym miastem, funkcjonuje tu znaczna liczba NGO, które aktywnie współpracują z jednostkami samorządu terytorialnego. W powiecie bieruńsko-lędzińskim ocena świadczonej opieki jest w znacznej mierze ambiwalentna ${ }^{16}$. Podobnie jak w powiecie nyskim, funkcjonuje tu duże stowarzyszenie, które zapewnia opiekę dla kilku tysięcy obecnych i byłych pracowników kopalni, ale nawet skala i niewątpliwa skuteczność podejmowanych przez ten podmiot interwencji nie kompensują znaczących braków instytucjonalnych i słabości holistycznie pojmowanego trzeciego sektora. Funkcjonuje tu niewiele organizacji zajmujących się opieką. Nieco inna sytuacja dotyczy powiatu wejherowskiego. W sensie ilościowym liczba organizacji pozarządowych zajmujących się opieką jest stosunkowo duża, ale nie ma tu znaczących organizacji obejmujących opieką większą rzeszę beneficjentów. Wskazuje się na znaczące braki instytucjonalne. Trzeci sektor jest „rozdrobniony”, co nie musi oznaczać jego słabości. Niemniej podkreśla się brak instytucji opieki nad dziećmi (żłobki, przedszkola). IDI wskazują, że rola i znaczenie wejherowskich NGO bez wątpienia będą w najbliższych latach wzrastać. Największym problemem jest tu brak koordynacji działań międzysektorowych. W odniesieniu do pozostałych powiatów ujętych w próbie badawczej negatywnie odznacza się powiat kazimierski. W powiecie brakuje instytucji opiekuńczych, co dotyczy także sektora publicznego. Można również stwierdzić tu deficyty kapitału społecznego i międzysektorowych partnerstw. Na podstawie stwierdzeń, opinii i sądów wyrażanych w IDI trzeba zauważyć, że opieka świadczona na rzecz wszystkich kategorii beneficjentów jest niedostateczna. Dotyczy to zarówno aktywności sektora społecznego, jak i opieki jako takiej. Aktywność trzeciego sektora niemal wyłącznie ogranicza się do działalności kół gospodyń wiejskich (co nie podważa ich ogólnego znaczenia w obszarze opieki).

\section{Podsumowanie}

Ważną konstatacją dotyczącą organizacji obywatelskich i ich aktywności w obszarze opieki jest ich swoista wielobranżowość. Materiał empiryczny dostarczył jednoznacznych dowodów świadczących o tym, że podmioty, które potencjalnie nie realizują działań

16 Mimo restrukturyzacji górnictwa powiat od lat charakteryzuje się jednym z najniższych współczynników bezrobocia, nie tylko w skali województwa śląskiego. Roczniki Statystyczne RP, Warszawa 2001-2015. 
opiekuńczych (np. koła gospodyń wiejskich, stowarzyszenia na rzecz rozwoju lokalnego) są bardzo aktywne w obszarze opieki realizowanej w skali mikro. Działania niektórych organizacji prowadzone na rzecz szerzej pojmowanego rozwoju lokalnego często trudno odróżnić od działań opiekuńczych (organizacja lokalnych przedsięwzięć kulturalnych, np. festynów, jest jednocześnie bardzo ważnym elementem aktywizacji społecznej osób starszych, chorych, niepełnosprawnych oraz dzieci). Również organizacje nastawione stricte na świadczenie opieki cechują się nieszablonowym podejściem do jej zapewnienia. Gdy pojawia się przeszkoda w zapewnieniu odpowiedniego wsparcia danej osobie lub grupie, organizacje obywatelskie raczej starają się znaleźć właściwe rozwiązanie z punktu widzenia beneficjenta. Nie unikają wyzwań, co znajduje potwierdzenie w materiale badawczym. Spośród grup beneficjentów opieki znajdujących się w orbicie analizy, wsparciem objęte są najczęściej osoby niepełnosprawne. Wynika to ze znaczących braków publicznych instytucji świadczących opiekę dla tej kategorii, co było wielokrotnie akcentowane w trakcie IDI.

W ramach podsumowania należy wskazać, że przeprowadzone badanie miało m.in. za zadanie rozpoznać opinie przedstawicieli trzeciego sektora na temat celów opieki oraz procesu jej deinstytucjonalizacji. Stworzona definicja operacyjna opieki jednoznacznie odnosi się do jej celów. Analiza nie dała jednak jednoznacznej odpowiedzi na pytanie o zasadność deinstytucjonalizacji. Choć proces przechodzenia od opieki stacjonarnej do środowiskowej można uznać za trend, to opinie na ten temat są podzielone. Przedstawiciele NGO potencjalnie wskazywani są jako główni dostarczyciele usług środowiskowych. Uczestnicy wywiadów prezentowali ambiwalentne opinie w zakresie zasadności jej powszechnego stosowania.

\section{Bibliografia}

Boschee J., Migracja od innowacyjności do przedsiębiorczości, [w:] Przedsiębiorstwo społeczne. Antologia kluczowych tekstów, red. J.J. Wygnański, FISE, Warszawa 2008.

Brinkerhoff J.M., Ramy definicyjne partnerstwa pomiędzy sektorem rządowym a organizacjami non-profit, [w:] Trzeci sektor dla zaawansowanych. Współczesne teorie trzeciego sektora - wybór tekstów, Klon/ Jawor, Warszawa 2006.

Goleński W., Rola odpowiedzialności obywatelskiej w modelu aktywnej polityki społecznej, [w:] Odpowiedzialność - przestrzeń lokalnego społeczeństwa obywatelskiego, biznesu i polityki, red. R. Geisler, IS UO, PTS, Opole 2013.

Goleński W., Spółdzielczość socjalna jako element zrównoważonego rozwoju, „Przegląd Nauk Stosowanych” 2014, nr 4 (4).

Granovetter M., Economic action and social structure: The problem of embeddedness, „American Journal of Sociology" 91, 1985.

Grewiński M., Wielosektorowa polityka społeczna. O przeobrażeniach państwa opiekuńczego, WSP, TWP, Warszawa 2009.

Grewiński M., Karwacki A., Pluralizm i międzysektorowa współpraca w realizacji usług społecznych, MCPS, Warszawa 2009.

Koczur W., Decentralizacja jako podstawa skutecznego rozwiązywania lokalnych problemów społecznych, [w:] Partnerstwo lokalne jako strategia rozwiązywania problemów społecznych, red. A. Frączkiewicz-Wronka, UE, Katowice 2010. 
Kramer R.M., Trzeci sektor w trzecim tysiącleciu, [w:] Trzeci sektor dla zaawansowanych. Współczesne teorie trzeciego sektora - wybór tekstów, Klon/Jawor, Warszawa 2006.

Putnam R.D., Demokracja w działaniu. Tradycje obywatelskie we współczesnych Włoszech, tłum. J. Szacki, Znak, Fundacja im. Stefana Batorego, Kraków-Warszawa 1995.

Roczniki Statystyczne RP, GUS, Warszawa 2001-2015.

Sztompka P., Zaufanie. Fundament społeczeństwa, Wydawnictwo Znak, Kraków 2007.

Wasylewski R., Lokalna polityka społeczna, [w:] Polityka społeczna, red. G. Firlit-Fesnak, M. Szylko-Skoczny, PWN, Warszawa 2007.

Węsierska L., Partnerstwa lokalne — droga do budowania spójności społecznej, [w:] Rozwój. O tym jak integracja środowisk lokalnych i uspołecznienie gospodarki budują nowa jakość, red. T. Sadowski, Barka, Poznań 2012.

Wygnański J.J., Ekonomizacja organizacji pozarządowych. Możliwość czy konieczność?, Klon/Jawor, Warszawa 2008.

\section{Diagnosis and analysis of the functioning of NGOs in the area of welfare in Poland. Conclusions from empirical studies}

Keywords: welfare/care, non-governmental organisations, third sector

\section{Summary}

Non-governmental organisations (NGOs), being important actors of social policy, constitute an essential link within local systems of welfare/care. This article presents the results and conclusions of a qualitative research carried out in six purposefully selected counties from the perspective of the diagnosis and analysis of the functioning of non-governmental organizations as part of the welfare system in Poland. They concern mainly the perception of welfare by representatives of the third sector, as well as different forms of its realization, the reasons and characteristics of the NGOs activities, the resources and expenditures related to the organization of their activities, inter-institutional cooperation and the overall assessment of these entities as a part of the local system of welfare. 